\title{
THE EU AND ENVIRONMENTAL PROTECTION: CYPRUS AT THE CROSSROADS OF EUROPE
}

\author{
Emine EMINEL SÜLÜN* \\ Zehra AZIZBEYLi ** \\ Araştırma Makalesi
}

\begin{abstract}
Environmental challenges are on the increase every day and the protection of European ecosystems is becoming more critical for the European Union (EU). Through the European environment policy framework, various instruments have been introduced but the Turkish Republic of Northern Cyprus (TRNC) is an exceptional case where the acquis communautaire is suspended until a political settlement is reached. This paper examines together the EU's ability in providing environmental security as an element of environmental protection within its borders and problematizes the EU engagement in the TRNC and environmental protection on the island. The EU's abilities and its capacity in the protection of the environment in Cyprus can be enhanced by engaging more with the Turkish Cypriot authorities on the issues of environmental protection.
\end{abstract}

Keywords: Environmental Protection, Europeanization, North Cyprus, the European Union

\section{Avrupa Birliği (AB) ve Çevrenin Korunması: Avrupa'nın Kavşağında Kıbrıs \\ $\ddot{O} z$}

Her geçen gün artan çevre kirliliğine bağll olarak, Avrupa ekosisteminin korunması Avrupa Birliği (AB) için daha da önemli bir mesele haline gelmektedir. Avrupa Çevre Politikaları çerçevesinde birtakım araçlar bu bağlamda mevcuttur ancak Kuzey Kıbrıs Türk Cumhuriyeti (KKTC), topluluk müktesebatının siyasi bir çözüme kadar askıya alındı̆̆ı sıra dışı bir durum olarak karşımıza çıkmaktadır. Bu makale, AB'nin kendi sınırları içinde çevre korumanın bir unsuru olarak çevre

* Asst. Prof., Near East University, E-mail: emine.sulun@neu.edu.tr, ORCID: 0000-00024175-7478.

** Dr., Near East University, E-mail: zehra.azizbeyli@neu.edu.tr, ORCID: 0000-0003-27788785.

Makalenin Gönderilme Tarihi: 18/08/2020 Kabul Edilme Tarihi: 09/04/2021 
güvenliğini să̆lama becerisini birlikte incelemekte ve AB'nin KKTC'deki katılımını ve adadaki çevre korumasını sorunsallaştırmaktadır. Makale, AB'nin Kıbrıs özelinde çevrenin korunması bağlamında kapasitesini artırabilmesi için Kıbrıslı Türk otoritelerle daha fazla ilişki kurmasını önermektedir.

Anahtar Sözcükler: Çevrenin Korunması, Avrupalılaşma, Kuzey Kıbrıs, Avrupa Birliği

\section{Introduction}

The Global Risks Report of 2020 was published to provide a perspective on the major threats facing our planet in 2020. Within this report, the World Economy Forum announced the five biggest global risks in 2020. ${ }^{1}$ One of the risks that is outlined by the report is anthropogenic environmental disasters. This includes environmental damages such as oil spills, nuclear contamination and water pollution. Interestingly, this is the first time in the Global Risks Report history that all critical threats are environmental. $^{2}$ Cyprus is a small country in the middle of the Mediterranean sea, but it is faced with man-made environmental damage on a daily basis. ${ }^{3}$ Moreover, the political impasse of the current situation also intensifies the environmental degradation and poses threats to the environmental protection of the island. A new study has found that coastal areas in north Cyprus have the "second highest amount of microplastics among beaches studied across the world". 4 This is no coincidence as marine and coastal ecosystems are poisoned with toxic pollution every day due to uncontrolled growth of smaller towns in TRNC. The current sewage systems are dated and insufficient to cope with such an overload, this in turn leads to spills. It is also reported that most of the luxury hotels lack proper sewage

1 “The Global Risks Report 2020”. 2020. World Economic Forum. Accessed August 13, 2020.

https://www.weforum.org/reports/the-global-risks-report-2020.

2 “The Global Risks Report 2020". 2020.

3 Furthermore, the year 2020 has brought new environmental problems. "COVID-19 has triggered an estimated global use of 129 billion face masks and 65 billion gloves every month. Single-use plastic has been used extensively as a result of increased usage and most of these plastic products end up either in landfills or in the ocean", For more information, please see: Scientific American, "COVID-19 Has Worsened the Ocean Plastic Pollution Problem", August 17, 2020. Accessed August 17, 2020, https://www.scientificamerican.com/article/covid-19-has-worsened-the-ocean-plasticpollution-problem/.

4 Ward, Nora. "Microplastic Pollution is at An All-Time High in Cyprus," Pacific Standard, November 26, 2018. Accessed August 13, 2020. https://psmag.com/environment/microplastic-pollution-is-at-an-all-time-high-in-cyprus. 
systems so eventually dump their waste into the sea. ${ }^{5}$ The representative of the Turkish Cypriot activist group, the Kyrenia Initiative, Safiye Özaltıner, said "tourists have on several occasions called in spills from pipelines carrying, what is suspected to be sewage from the nearby hotels." ${ }^{.6}$ Against this background, the origin of this paper is twofold: firstly, to illustrate the threat of the EU's non-recognition policy on the environmental protection of the island and to highlight the EU's ability in enhancing environmental cooperation in the de facto partitioned Cyprus. Theoretically, this paper discusses both how the EU deals with the environmental protection of the TRNC in the absence of international recognition, efficient government and territorial rule, $^{7}$ and the EU's potential of providing environmental cooperation schemes for the protection of the whole ecosystem of the island in the given context. With this aim, the paper explores in depth the EU's engagement in the TRNC and the issues of environmental protection.

This paper argues that sui generis political nature of the TRNC affects the EU's environmental legislation in areas which are de jure part of the Union and hampers the Union's endeavors in tackling environmental problems within its borders. The main purpose of this case study is to describe the availability and instrumentality of the framework of European environment policy for Cyprus, in particular the TRNC, and the extent to which this framework communicates with the wider EU objectives of triggering bi-communal environmental cooperation on the island. The availability and instrumentality of the framework of the European environment policy is generally defined as the implementation of various tools and instruments that have been introduced within that context. This paper follows with a brief overview of the historical background of the Cyprus Problem. It then moves on to delineate the conceptual and methodological boundaries of the study. Further it discusses the environmental aspect of unrecognition on environmental pollution in north Cyprus. Finally, this paper discusses limitations related to the issue of environmental protection and the EU policy of engagement with the authorities in north Cyprus.

5 CYPRUS: Sewage spills, sea pollution the norm for historic harbour towns. (2019, September 22). Financial Mirror. Accessed March 09,2021. https://www.financialmirror.com/2019/09/22/cyprus-sewage-spills-sea-pollution-thenorm-for-historic-harbour-town/

6 CYPRUS: Sewage spills.

7 Bouris, Dimitris and George Kyris, "Europeanisation, Sovereignty and Contested States: The EU in Northern Cyprus And Palestine". The British Journal of Politics and International Relations 19(4): 755-771(2017). doi:10.1177/1369148117727534. 


\section{The Political Situation in Cyprus}

Cyprus is situated at the intersection of Africa, Asia and Europe; it is accepted as among the oldest civilizations in the Mediterranean. Over the centuries, the island became a meeting point of East and West due to its geostrategic position. It was not until 1960 that an independent Republic of Cyprus (RoC) was established as a bi-communal republic, as the society was predominantly made up of Greek speaking Orthodox Christians - Greek Cypriots and the Turkish speaking Muslims - Turkish Cypriots with two separate nationalist movements that eventually led to inter-ethnic violence in 1963. The year 1974 was marked as a catastrophe for Cypriots as several thousands were killed, went missing and were displaced from both communities due to the troubles. Since then, the island has been divided into two parts and the situation is identified as the Cyprus problem. In the southern part there is the Greek Cypriot administration that is also known as the Republic of Cyprus (RoC) and in the north the Turkish-Cypriot administration, which unilaterally established itself as the Turkish Republic of Northern Cyprus (TRNC) in $1983 .{ }^{8}$ The TRNC is an entity that has a certain "population, a territory, a government and capacity to enter into relations with third states". ${ }^{9}$ It is not recognized by any state other than the Republic of Turkey and therefore acts as a de-facto state..$^{10}$ The Republic of Cyprus (RoC) acts as the legal representative of Cyprus. The TRNC enjoys internal sovereignty as it refers to effective state structures and authoritythat is also known as empirical statehood ${ }^{11}$ and has also external relations through non-recognition and contested statehood with a number of actors including the EU.

8 The military offensive of Turkey in 1974 is popularly known as the "Turkish occupation/ Turkish invasion" is the definition of the Greek Cypriots. Among Turkish speakers the operation is also referred as "Cyprus Peace Operation" with the claim that Turkey's military action was caused by the Greek-led coup and therefore acted as a peacekeeping operation with the aim of the protection of Turkish Cypriots. The terminology reflects the representation of words as part of the lexical choices to define the Cyprus conflict.

9 Bouris and Kyris, Europeanisation, Sovereignty and Contested States.

10 The literature on sovereignty and de-facto states includes researchers like Eiki Berg, Nina Caspersen, James Ker-Lindsay, Bruno Coppieters and Rebecca Bryant. "The term de facto refers to a place exercising internal sovereignty over its subjects. However, it is not recognized by most of the world as the de jure legal authority in that territory. Usually, de facto states are separated from an internationally recognized state that claims sovereignty over the territory. Fundamentally, a patron state supports them both financially militarily but in return the patron state is believed to be involved in internal affairs. See, De Waal, Thomas. Uncertain Ground: Engaging with Europe's de Facto States and Breakaway Territories. Carnegie Europe, 2018 for further reference.

11 Bouris and Kyris, Europeanisation, Sovereignty and Contested States. 
The EU has a policy of non-recognition vis-à-vis the authorities in north Cyprus. This policy is based on the argument that the TRNC's declaration of independence in 1983 is contradictory crucially with the two treaties of the RoC that are known as the Treaty of Establishment and the Treaty of Guarantee. Yet, "a policy of non-recognition means more than the absence of recognition" 12 and one needs to look at the nature of the EU's policy of non-recognition or in other words how the Union engages with the people of such entities through its policies of engagement. In a tense dynamic between the two, a policy of engagement would trump a policy of non-recognition and build a cooperation on an administrative level between the EU officials and the authorities in de-facto states. Since a policy of non-recognition is based on denying statehood of de-facto authorities, any engagement which would strengthen state institutions has to be avoided by the EU. This requires a very sensitive engagement policy based on a pragmatic approach of collaboration with the governmental officials. Those officials should not be granted any kind of official position in making statements or communiques as this would indicate a strengthening of the legal position of the de facto regime in north Cyprus within that formulation.

According to Kyris ${ }^{13}$, the way that the EU deals with the conflict in Cyprus and the way it engages with the community in the north has been largely informed by ideas of sovereignty. When the RoC applied to join the EU in the 1990s, the main assumption was that an EU membership could trigger a political settlement. Yet, on $24^{\text {th }}$ April 2004, the UN backed Annan Plan ${ }^{14}$ was rejected in an island -wide referendum. 65 percent of Turkish Cypriots voted in favour of the plan, whereas 76 percent of Greek Cypriots voted in rejection. As a result, in May 2004, a divided Cyprus, represented by the RoC became an EU member-state. George Kyris ${ }^{15}$ asserts, in the beginning it was hoped that this accession of the RoC would act as a catalyst for unification and push both sides to work closer for a re-unified Cyprus, but the EU became an important motive for the RoC to refuse the UN Plan as they had already secured EU entry. Today, the EU law is inapplicable in half the country and Turkish-Cypriots do not partake in the EU policy

12 Talmon, 2005, p.101 cited in Coppieters, Bruno. "'Statehood', 'de facto Authorities' and 'Occupation': Contested Concepts and the EU's Engagement in its European Neighborhood." Ethnopolitics 17, no. 4 (2018): 343-361. p.346.

13 Kyris, George. "Sovereignty and engagement without recognition: Explaining the failure of conflict resolution in Cyprus." Ethnopolitics 17, no. 4 (2018): 426-442, p.4.

14 The plan suggested a United Cyprus Republic with two constituent states.

15 Kyris, George. "The European Union and Cyprus: The Awkward Partnership." Euractiv. April 2, 2013. Accessed August 13, 2020. https://www.euractiv.com/section/eurofinance/opinion/the-european-union-and-cyprus-the-awkward-partnership/ 
making. They continue to have limited interaction with Brussels due to the unrecognition of the northern part of Cyprus as a state. ${ }^{16}$ Kyris ${ }^{17}$ points out that the unequal treatment of the Turkish Cypriots gets more evident at such times as the Greek Cypriots often limit the EU to interact with the Turkish Cypriot community as they carry the legal membership of the EU club. Most importantly, despite the Union's comprehensive environmental policy framework, the division is hampering efforts by the Union in addressing environmental problems in its entirety.

\section{Conceptual and Methodological Considerations}

At the conceptual level, the present paper has been largely informed by the idea that environmental problems and protection of the environment can be better addressed when they are conceptualized within the environmental security framework. They are also issue areas for policy-making processes. From this perspective, the EU has developed numerous tools and mechanisms to deal with environmental threats against individuals within its borders. Yet, the EU might have limitations in its capacity given the fact of different political contexts within its borders. This paper provides some insightful evidence on the trajectory of Europeanization of environmental policies through related programmes and projects in Cyprus. Thereby, it reflects on the development of tools and mechanisms the EU would have in dealing with environmental threats to individuals and communities within its borders, especially in the territorially disputed areas.

This paper is a qualitative case-study. ${ }^{18}$ For data collection, secondary sources were reviewed including governmental and media reports, official documents as well as academic articles. Furthermore, a set of semistructured consultations were held with administrative elites that are familiar with the EU policies in the northern part of the island. Thematic analysis is used for data analysis. ${ }^{19}$ This paper takes the concept of environmental protection as an element of environmental security. Building on a tradition of security studies, Baldwin defines security as a "low probability of damage

16 Kyris, The European Union and Cyprus.

17 Kyris, Sovereignty and engagement without recognition.

18 Creswell, John W., and J. David Creswell. Research design: Qualitative, quantitative, and mixed methods approaches. Sage publications, 2017.

19 See Nowell, Lorelli S., Jill M. Norris, Deborah E. White, and Nancy J. Moules. "Thematic analysis: Striving to meet the trustworthiness criteria." International journal of qualitative methods 16, no. 1 (2017): 1609406917733847. 
to acquired values," ${ }^{20}$ and argues that this definition should be adopted to specific issue areas by addressing the following questions: Security for whom? Security for which values? From what threats? Based on these questions, the following two subsections aim to adopt this perspective of environmental protection by asking similar questions in the context of environmental problems and Cyprus.

\section{A. Whose Security? What are the Threats?}

The security of individuals and societies have always been largely determined by local environmental conditions throughout the history of mankind. The length of individuals' lives and the rate of diseases have been invariably determined by conditions and changes in the environmental ecosystem. ${ }^{21}$ In today's modern societies, the challenges that local environmental conditions set on human security may have been better identified but cannot be tackled entirely. Human activity over the past 150 years has warmed the earth to unprecedented degrees. ${ }^{22}$ Security of individuals and communities is intrinsically linked to the security and sustainability of ecosystems and species. In this respect, the EU is facing various problems and is expected to develop an environmental policy. This paper points to the role of the EU to mitigate the causes of these environmental changes and to facilitate responses in minimizing insecurities of communities within its borders.

In our pursuit of understanding the EU, environmental protection and pollution, and north Cyprus, we mainly ask the questions: Who is to be secured from what? By whom will they be secured? How will they be secured? In an overview of contemporary security threats, human security appears to be as important as the traditional state-centric understanding of security, which encapsulates the state as the main referent object of its core analysis in the concept of national security. ${ }^{23}$ In contrast to the dominant state-centric approach as such, human security views the individuals and communities as the entities to secure in themselves. ${ }^{24}$ The motivation of

20 Baldwin, David A. "The concept of security." Review of international studies 23, no. 1 (1997): 5-26.

21 McDonald, B. L., Matthew, R., Barnett, J., \& O'Brien, K. (2009). Global Environmental Change and Human Security. The MIT Press.

22 "The Causes of Climate Change." NASA. February 8, 2021. https://climate.nasa.gov/causes/.

23 Kerr, Pauline "Human security and diplomacy." In Cavelty, Myriam Dunn, and Victor Mauer, eds. The Routledge Handbook of Security Studies. Routledge, 2010. (pp. 115-127), p.115.

24 See UNDP. 1994. Human Development Report 1994: New Dimensions of Human Security. Accessed August 13,2020. http://www.hdr.undp.org/en/content/human- 
thinking about the community dimensions of environmental change and its link to security, directed the present research to negotiate the meaning of human security in a way to challenge the idea of strengthening the state at the expense of human security. ${ }^{25}$ Such a consideration leads us to search for alternative actors other than the state who can address threats to human life that are associated with environmental changes. The EU, in that respect, has distinct structures of governance in the field of environment as a transnational entity. Nonetheless, Cyprus is a unique case in terms of the Europeanization of structures of environmental governance, in the sense that the acquis communitarian ${ }^{26}$ is suspended in the areas of Cyprus, in which the Government of the RoC does not have control until a comprehensive settlement of the Cyprus problem has been reached. In the given context, because of the suspension of the acquis communitarian in the north, bicommunal environmental corporation schemes appear to be the most important instruments for the environmental protection of the island as a whole. In relation to these, the context in which the EU encourages environmental cooperation in Cyprus and the relevance of the EU's environmental governance for the TRNC is further discussed below.

\section{B. Environmental Cooperation and Europeanization of Structures of Environmental Governance in the TRNC}

Environmental peacebuilding, as a field of environmental cooperation, has developed from the broad field of environment, conflict and peace, merging a number of connections that focus on environmental threats caused by conflicts as well as environmental opportunities for peace. It is a field of cooperation, a win-win solution to escape from the zero-sum logic of conflict. ${ }^{27}$ There are four conceptual relationships between the environment and conflict: "the environment as a tool for conflict resolution, or as a source of conflict, environmental damage as a result of conflict, and the creation of de-facto ecological havens in demilitarized zones". ${ }^{28}$ Cyprus displays all four possibilities at different levels, but this article focuses on the EU's capacity and willingness in using the environment as a tool for cooperation.

development-report-1994.” p.25. See also "Global Environment Outlook 1: For Life On Earth. 1997”. UNEP. Accessed August 13,2020.

25 McDonald, B. L., et.al. Global Environmental Change. p.20.

26 The common body of law regulating trade and movement within the EU.

27 Dresse, Anaïs, Itay Fischhendler, Jonas Østergaard Nielsen and Dimitrios Zikos. "Environmental peacebuilding: Towards a theoretical framework." Cooperation and Conflict 54, no.1 (2019):99-119.

28 Jarraud, Nicolas Stephane and Alexandros Lordos, "Participatory Approaches to Environmental Conflict Resolution In Cyprus", Conflict Resolution Quarterly, (2012), 29(3), pp. 261 
The EU encourages environmental cooperation on the island through funding bi-communal environmental projects. These projects are part of the EU Aid Programme for the Turkish Cypriot community that supports the Turkish Cypriot community and aims to strengthen civil society in the northern part of Cyprus. It is viewed as "a key factor in the development of a culture of dialogue, participation in community life, and the promotion of values of tolerance, peace, active citizenship" ${ }^{29}$ From an EU perspective, aid regulation 389/2006 was approved to help prepare for reunification of the island. For this purpose, the Commission assigned $€ 259$ million for a 5-year programme. Since 2006, a total of $€ 449$ million has been programmed under Aid Regulation. One example of an EU funded environmental project is the NATURA 2000 project, which set out to prepare control plans for the protection of special environmentally protected areas in the northern part of Cyprus. The aim was to convert these areas into a "Natura 2000" site after a comprehensive settlement between the two communities was reached. Moreover, the project aimed to provide support for building the professional capacity of Turkish Cypriot participants. Karpaz Park, Akdeniz Region, South Karpaz coastal area, Kyrenia Mountains, Tatli Su coastal area, and the Alagadi beaches were part of this project. ${ }^{30}$

Through the environmental acquis which encompasses more than 300 environmental issues, the EU policy making field within the environmental policy appears to be relatively competent. ${ }^{31}$ How is that structure relevant for the TRNC? It is possible to look at the impact of Europeanization through analysis of policy, polity and politics. ${ }^{32}$ For instance, with an endeavour of understanding the EU policy making, most of the studies look at policy content, administrative structures, and regulatory style within the environmental policy. ${ }^{33}$ Certainly, there is an extensive deal of political activity ongoing at EU level and the Union has evolved into a legislative focus in various issue areas and thus has become a primary reference point

29 Hadjimichael, Maria and Klitos Papastylianou, "Environmental protection and cooperation in an (ethnically) divided island: The case of Cyprus", Report 6/2019/Peace Research Institute Oslo (PRIO), Norway.

30 For more information, please see https://ec.europa.eu/cyprus/about-us/turkish-cypriots_en

31 Börzel, Tanja, A. "Environmental Policy". In Europeanization: New Research Agendas. ed. Paolo $\backslash$ Graziano and Maarten Vink (Palgrave Macmillan: 2008), 226-238. p.227.

32 Börzel, Tanja A., "Europeanization: How the European Union Interacts with its Member States", In The member states of the European Union. ed. Simon, Bulmer and Christian Lequesne, (USA: Oxford University Press: 2005), 45-69; Börzel, Tanja and Thomas Risse, "Conceptualising the Domestic Impact of Europe", In The Politics of Europeanization. ed. Kevin Featherstone and Claudio M. Radaelli, (Oxford: Oxford University Press: 2003), 57-79.

33 For an extensive overview of the related literature see Börzel, Environmental Policy. 
for the Member States. This indicates a shift in levels of authority with some meaningful effects for domestic politics. Although it is beyond doubt that European integration in that sense has an effect on the member states, the magnitude and the nature of such an influence on domestic politics are not self-explanatory phenomena. This is where the Europeanization framework steps in as a research agenda to fill this gap. ${ }^{34}$ Caporaso $^{35}$ points out a wide range of possible national responses: "Member states may ignore what happens in Brussels, they may automatically "download" what takes place there, they may show creativity in the way they implement directives, and they may transform their domestic structures so as to accomplish the goals set up in Brussels" ${ }^{\prime 36}$. According to a top-down model, Europeanization works through a degree of pressure, which can be understood via the degree of structural similarities and differences between European and domestic level. Nonetheless, this pressure itself is not the only condition for domestic change as cross-country differences are mostly because of the role played by mediating factors as well as domestic structural change. ${ }^{37}$ It is possible to say that they all interact with each other within the system.

The way Europeanization is incorporated into this article is more of a bottom-up approach which looks at domestic players, problems, and resources, starting and ending at a domestic level. Acknowledging the harmonization process in a certain issue area is not sufficient to indicate Europeanization in that specific field. This paper is interested in understanding the extent to which the logic of EU politics can penetrate the domestic political life of a member state, where the acquis communitarian cannot be applied properly. After the island became a de jure member-state in 2004, an upward cooperation was noted between the EU and domestic policy-makers of north Cyprus. It is possible to argue that the socialization process primarily takes place through know-how instruments with the provision of the EU expertise and technical help. ${ }^{38}$ Accordingly, the next section looks at available instruments at the hand of the Union within the field of environmental policies and the degree in which these are transferred to north Cyprus during the accession and in the post-accession period.

34 Caporaso, James, "The Three Worlds of Regional Integration Theory". In Europeanization: New Research Agendas. ed. Paolo, Graziano and Maarten Vink, (Palgrave, Macmillan: 2008), 23-25. p.28.

35 Caporaso, The Three Worlds of Regional Integration Theory, pp.28-29.

36 Ibid.

37 See Caporaso, The Three Worlds of Regional Integration Theory, for further discussion of these factors.

38 Throughout this socialization process, a new set of actors as new elites can be seen with their particular beliefs, actions, interests and discourses. It would be interesting to further look at the extent to which these new elites can be discerned in the case of north Cyprus. 


\section{Environmental Protection and the Non-Recognition of the TRNC}

In the last couple of years, local Turkish Cypriot newspapers have published data showing toxic pollution levels in coastal towns such as Kyrenia: "A Big Threat for Coasts in the TRNC!"39 "Waste is swimming not people" $"$, "The sewage fear has hit the beaches" 41 ,"Four thousand cubic meters of wastewater is pumped into the sea every day" 42 " "Lack of Treating the Water Turns into a Disaster" ${ }^{\prime 43}$ are only a few of the headlines that have been used in recent years by the Turkish Cypriot Press. Moreover, the summer of 2020 also witnessed an invasion of jellyfish along the coast of Cyprus, where the Mediterranean is becoming a climate change spot intimidating ecosystems with global warming resulting in unusual occurrences such as tropical jellyfish on Cyprus shores. ${ }^{44}$ Indo-Pacific species, Pterois miles, is another alien species appearing as a major invasive threat in the eastern Mediterranean Sea over the last few years. ${ }^{45}$ Marine researchers are alarmed at how quickly environmental change has intensified existing problems in the Mediterranean Basin with a mix of changes in land

39 Kıbrıs Ada Haber. "KKTC Sahilleri İçin Tehlike,” October 30, 2013. Accessed August 13, 2020. https://www.kibrisadahaber.com/mobi/kktc-sahilleri-icin-tehlike.html.

40 Yenidüzen Gazetesi. "Waste is Swimming Not People," September 5, 2017. Accessed August 13, 2020. http://www.yeniduzen.com/insanlar-degil-atiklar-yuzdu-93587h.htm.

41 Havadis. "People are Hit by the Fear of Sewage," July 16, 2017. Accessed August 13, 2020. https://www.havadiskibris.com/lagim-korkusu-plajlari-vurdu/.

42 Yenidüzen Gazetesi, “Outdated Sewage Plant Damaging Environment,” June 06, 2018. Accessed August 13, 2020. https://www.lgcnews.com/outdated-sewage-plant-damagingenvironment/; Yenidüzen Gazetesi, "4 thousand cubic meters of wastewater is pumped into the sea per day," June 06, 2018. Accessed August 13, 2020. http://www.yeniduzen.com/gunde-4-bin-metrekup-atik-su-denize-pompalaniyor103212h.htm

43 Kıbrıs Gazetesi. "Arıtma yetersizliği felakete dönüşüyor,” October 06, 2019. Accessed August 13, 2020. https://www.kibrisgazetesi.com/kibris/aritma-yetersizligi-felaketedonusuyor-

h75007.html?_cf_chl_jschl_tk_=5a8339ef0b91ce26f5b6a9c58a47361aaea1883f1580334695-0-

Ac_wJfbvhrav_pTBrxsaEG110kcR0oRllRqX4K6ysfA87Hqp8iJ9x0kvuYbNdpDvEwZ sqR6k7DFFd_cc4idSsqMPLl

44 Killaris, Kyriacos, "Global warming brings jellyfish invasion," August 10, 2020. Accessed August 14, 2020. https://www.financialmirror.com/2020/08/10/global-warming-bringsjellyfish-invasion/

45 Bilecenoğlu, Murat. "Controlling the Lionfish Invasion in the Eastern Mediterranean Sea", In Lionfish Invasion and Its Management in the Mediterranean Sea, ed. Fatih M. Hüseyinoglu and Bayram Öztük. (Istanbul: Turkish Marine Research Foundation, TUDAV: 2018), 1-10.p.1. 
use. $^{46}$ The case of the TRNC displays how an absence of international recognition can be detrimental for tackling urgent environmental problems. With the impact of economic and political embargoes, the economy of north Cyprus continues to struggle in eradicating the difference in income between itself and the southern part of the island. For these reasons, the northern Cypriot economy relies entirely on foreign assistance, where Turkey extends economic aid packages to the TRNC every year. ${ }^{47}$ Non-recognition makes it very difficult to cooperate at an official administrative level with the Republic of Cyprus, where the latter persistently rejects conducting official meetings with the Turkish Cypriot side. Non-recognition also hinders environmental governance on an EU level to propose frameworks and create, validate or change institutions in the north. ${ }^{48}$

Across the island there is a degree of understanding that toxic pollution knows no borders, no checkpoints or political division. Formed in 2008, 'The Bi-communal Technical Committee' is composed of five Turkish Cypriot and 6 Greek Cypriot environmentalists and experts as members who seek to work on conceptual notes that are advised by the leaders of the two communities. It is directed by the Presidential offices of both communities and has proven that coordination is possible between the two sides on persisting matters calling for environmental action. Ms. Şerife Gündüz, the former Turkish Cypriot head of the Committee, has listed its priorities as keeping green spaces, prioritizing river projects and coastal cleaning on both sides of the divide. Nonetheless, she further highlighted the weak environmental law and lack of penalties in the north of the island. ${ }^{49}$ While stressing the significance of the EU level responses, she reminded the importance of adaptation of EU legislations and directives for the TRNC. ${ }^{50}$ Based on that, the following section discusses the trajectory of the harmonization of EU environmental legislation in north Cyprus.

46 Killaris, Global warming brings jellyfish invasion.

47 The most recent collaboration between the Republic of Turkey and the TRNC took place in early March 2021 where they signed Turkey-TRNC 2021 Economic and Monetary Cooperation Agreement and 2.5 billion liras (\$336.83 million) of new resources were allocated to the TRNC in 2021 (For more info, please see: https://www.aa.com.tr/en/europe/turkey-turkish-cyprus-sign-financial-cooperationpact/2164021).

48 Dresse, et.al. Environmental peacebuilding.

49 Ms. Şerife Gündüz (The President of "The Bicommunal Technical Committee on Environment" in Cyprus), interview with the authors, February 15, 2020, Nicosia.

50 Ms. Şerife Gündüz, interview with the authors. 


\section{A. The TRNC and Harmonization of EU Legislations and Directives}

The European Union has had the legislative power on environmental matters since 1986. There was already a wide-ranging body of environmental legislation before 1986, driven by market-making and market-correcting policies. ${ }^{51}$ There has been no pressure for the adaptation of these legislations for the TRNC, but only a process of demand-driven harmonization of legislations and directives until a political settlement is reached. For the $R o C$, in which the acquis communitarian is de jure, it is possible to see the environmental policies and changes in the administrative structures and regulations. This is problematic in the sense that the Union aims to achieve an integrated way of coastal management. ${ }^{52}$ According to experts in the field, pollution in the north negatively affects the ecosystem in the south and the rest of Europe. ${ }^{53}$ Özden et.al. ${ }^{54}$ provide insights into the threat of anthropogenic marine litter (mostly the plastic and polystyrene litter) along the coast of North Cyprus and suggest poor domestic waste governance in the region as the main cause of the problem. The study illustrates how marine litter can easily travel across territories. The European Environment Agency considers European seas to incorporate a wide scope of marine and coastal ecosystems. The range and appropriation examples of these environments shift across territorial oceans, with the Mediterranean facilitating the most elevated characteristic biodiversity. Furthermore, coastal zones are accepted as among the weakest areas to climate change and natural hazards. ${ }^{55}$ Lack of cooperation on that matter between the TRNC and the rest of the EU appears to hamper the Union's integrated way of coastal management to unprecedented degrees. ${ }^{56}$ This can have negative ramifications for the conveyance of environment administrations whereupon human communities depend, especially in the marine domain. ${ }^{57}$

51 Börzel, Environmental Policy, p.226.

52 "Integrated Coastal Management - Environment - European Commission". 2020. Accessed August 13, 2020. https://ec.europa.eu/environment/iczm/index_en.htm.

53 Prof. Dr. Özge Özden Fuller (Academic, Near East University, Cyprus), interview with the authors, February 21, 2020, Nicosia.

54 Özden, Özge, Sinem Yıldırım, Wayne J. Fuller, and Brendan J. Godley. "Anthropogenic marine litter on the north coast of Cyprus: Insights into marine pollution in the eastern Mediterranean." Marine Pollution Bulletin 165 (2021): 112167.

55 "6: World Oceans and Coastal Zones." IPCC. Accessed March 14, 2021. https://www.ipcc.ch/report/ar1/wg2/world-oceans-and-coastal-zones/.

56 Prof. Dr. Özge Özden Fuller, interview with the authors.

57 "The EU environmental policy responses in the marine domain include the Marine Strategy Framework Directive (MSFD), the Common Fisheries Policy (CFP), the 7th Environment Action Programme, the 2020 Biodiversity Strategy, and legislation such as the Birds Directive, Habitats Directive and Water Framework Directive. The MSFD, as the environmental pillar of the Integrated Maritime Policy (IMP), is the key component of the 
Illustratively, the head of Lapta-Alsancak-Karşıyaka Fishermen's Union, Ertunç Birinci, warns of the threat of Lagocephalus sceleratus and Pterois miles for the sustainable use of the seas and conservation of marine ecosystems in north Cyprus, urging authorities to adopt necessary legislations and environmental instruments to help fishermen in the face of the increasing population of these two invasive species. ${ }^{58}$

In terms of the environmental administration, the RoC has adopted a sizable number of legislations, environmental instruments and programmes in the context of environmental policy. ${ }^{59}$ Besides the EU, in terms of the international instruments, the $\mathrm{RoC}$ draws legislation also from the United Nations Conventions concerning the environment, such as the implementation of the Mediterranean Action Plan (MAP) of the United Nations. In retrospect, environmental legislation began back in 1991 when the first environmental legislation bills were adopted, mostly about water and air protection from industrial pollution. Post-2004 the RoC initiated implementing the Union's environmental governance understanding, the mechanisms for implementation, application and enforcement of the environmental legislations in their entirety. Today, in excess of 200 laws and regulations can be found within almost every environmental category. Referring back to the TRNC, there has been an adaptation process of EU laws since 2004, including the ones on environment. To facilitate the adaptation process in general the action programme Financial Aid Regulation (FAR) was introduced in 2006. It aims to assist development grounding for implementation of EU law, and the Green Line Regulation (GLR) that enables trade between the two communities. ${ }^{60}$ One of the first actions of the European Union in the post-2004 period was to approve the Green Line Regulation ${ }^{61}$ in order to manage the "Green Line" that divides the government-controlled areas in the south from the rest of the island. The

EU's policy response to achieve healthy, clean and productive seas. See "Marine Environment". European Environment Agency. February 18, 2015. Accessed August 13, 2020. https://www.eea.europa.eu/soer-2015/europe/marine-and-coastal\#tab-based-onindicators for further information.

58 Balıkçıların sorunları neler? [What are the problems of fishermens?], (November 11, 2020). Gündem Kibris. Accessed March 12,2021. https://www.gundemkibris.com/kibris/balikcilarin-sorunlari-neler-h302654.html

59 For further information see "DEPARTMENT OF ENVIRONMENT - History". Republic of Cyprus (RoC). 2020. Accessed August 13, 2020. http://www.moa.gov.cy/moa/environment/environmentnew.nsf/page03_en/page03_en?Op enDocument

${ }^{60}$ Bouris and Kyris, Europeanisation, Sovereignty and Contested States.

61 "CELEX1, Council Regulation (EC) No 866/2004 Of 29 April 2004 On A Regime Under Article 2 Of Protocol 10 To The Act Of Accession”. Accessed August 13, 2020. https://op.europa.eu/en/publication-detail/-/publication/e68c4cc7-5783-4809-af6a$79 \mathrm{~d} 708 \mathrm{db} 7 \mathrm{a} 0 \mathrm{c}$. 
Regulation is about the movement of persons and goods across the divide and is run by the DG Regional and Urban Policy Task Force for the Turkish Cypriot Community, in which an annual report is prepared. This report is then adopted by the Commission and sent to the Council. In two years', the Council approved the "Aid" Regulation. ${ }^{62}$ The EU Aid Programme follows five different objectives considering the situation of the Turkish Cypriot community: The promotion of social and economic development; developing-refurbishing infrastructure (particularly energy, transport, environment, telecommunications and water supply); fostering reconciliation; building confidence and support for the civil society; bringing the Turkish Cypriot community closer to the EU, and helping the Turkish Cypriot community prepare for the implementation of EU law once a comprehensive settlement of the Cyprus issue is agreed. ${ }^{63}$ The assistance would benefit the Turkish Cypriot community via its "local bodies, cooperatives and representatives of civil society, in particular organizations of the social partners, business support organizations, bodies carrying out functions in the general interest in the areas, local or traditional communities, associations, foundations, non-profit organizations, NGOs, and natural and legal persons". ${ }^{64}$ The scheme described here has emphasized that the programme would not indicate any kind of recognition of any public authority in "the areas" other than the authority of the Republic of Cyprus. This is in parallel with the UN Resolution no. 541 which, "Deplored the declaration of the Turkish Cypriot authorities of the alleged secession of part of the Republic of Cyprus and considered the declaration of the TRNC as legally invalid and called for its withdrawal". ${ }^{65}$

The EU works with the TRNC officials on a lower profile level with a Brussels -based taskforce and a local programme support office. It can be said that there are unconventional ways in which the EU and the TRNC cooperate, this is also a significant point for understanding commitment with

62“"EUR-Lex - 32006R0389 - EN - EUR-Lex”. 2006. Accessed August 13, 2020. https://eurlex.europa.eu/legal-content/EN/TXT/?uri=CELEX\%3A32006R0389.

63“"Aid Programme for The Turkish Cypriot Community". 2020. European Commission European Commission. Accessed August 13. 2020. https://ec.europa.eu/info/fundingtenders/funding-opportunities/funding-programmes/overview-funding-programmes/aidprogramme-turkish-cypriot-community_en.

64 "Aid Programme for The Turkish Cypriot Community".

65"Security Council Resolution 541 - UNSCR”. 1983. UNSCR. Accessed August 13, 2020. http://unscr.com/en/resolutions/541; and "Security Council Resolution 550 - UNSCR". 1984. UNSCR. Accessed August 13, 2020. http://unscr.com/en/resolutions/550. For further discussion of the issue of recognition see Constantinou, Costas M., and Yiannis Papadakis. "The Cypriot state (s) in situ: Cross-ethnic contact and the discourse of recognition." Global Society 15, no. 2 (2001): 125-148. Constantinou and Papadakis state that one of the major political aims of the Greek Cypriot authorities after 1974 has been to obstruct any "normalisation" of the regime in the north. 
unrecognized states. ${ }^{66}$ This can also be seen as 'engagement without recognition' as part of the EU activities in Cyprus. James Ker-Lindsay ${ }^{67}$ explains this as the limits of diplomatic interaction with contested states. In overall terms, the TRNC lacks international recognition and in parallel to that, international instrument of environmental protection too. The next part of this paper discusses how the Union responds to this the sui generis case in the field of environment by further analyzing unconventional ways in which the EU and the TRNC cooperate.

\section{A Discussion on the Limitations of the EU's Engagement with North Cyprus within the Field of Environment}

In case of the environmental concerns, the EU has followed various management plans for the areas that needed assistance in terms of nature protection, waste management, water management, nature and biodiversity, green infrastructure, air quality, water quality and management, soil protection and marine protection, enhancing the sustainability of cities in general and implementing international agreements. ${ }^{68}$ According to EU laws, the necessary mitigation measures should be properly applied by the member states. For instance, in its annual Environmental Implementation Review of the year 2019, the European Commission mentioned that for Cyprus, the Convention for the Protection of the Marine Environment and the Coastal Region of the Mediterranean (Barcelona Convention) play an important role in achieving the goals required by the Marine Strategy Framework Directive (MSFD). These assessments only apply to the RoC as part of the environmental policies of the European Union and not to the TRNC.

The EU has partial integration with the Turkish Cypriot authorities, ${ }^{69}$ especially through two main structures: the EU Programme Support Office $(\text { EUPSO })^{70}$ and the European Union Coordination Centre (EUCC) $)^{71}$ both in

${ }^{66}$ Kyris, Sovereignty and engagement without recognition.

${ }^{67}$ Ker-Lindsay, James. "Engagement without recognition: The limits of diplomatic interaction with contested states." International Affairs 91, no. 2 (2015): 267-285.

${ }^{68}$ As of 2019, in terms of international agreements, Cyprus has signed but not yet ratified the Kiev Protocol on Pollutant Release and Transfer Registers and the Protocol on Strategic Environmental Assessment to the Espoo Convention. It has neither signed nor ratified the Protocol on Integrated Coastal Zone Management or the Helsinki Convention on Watercourses and Lakes. For more information, please visit https://ec.europa.eu/info/departments/environment_en.

${ }^{69}$ Kyris, The Europeanisation of Contested Statehood.

70 The office assists interactions with the recipient community of Turkish Cypriots, with a view to safeguarding cost-effective coordination, preparation and implementation of the support, and also to provide a site for meetings and seminars. 
the northern part of Cyprus. The EUPSO has been operational since September 2006 undertaking preparatory activities as a "ghost office" in the words of an EU bureaucrat. ${ }^{72}$ There have been important environmental projects coordinated by the European Union Coordination Centre (EUCC) and the EU in north Cyprus such as: Dikmen Rehabilitation Centre, Haspolat Waste-water Treatment Plant, Morphou Wastewater Treatment Plant, and the construction of a sanitary landfill site at Koutsoventis/Güngör, where modern waste compactors reinforce the fleet that collects and transports general waste to the central EU-funded non-hazardous sanitary landfill at Koutsoventis/Güngör. These are specific examples of the EU Aid Programme pertaining to activities carried out regarding environmental protection. However, in order to provide an analysis on the EU Aid Programme; cultural practices, institutional designs and legitimization of the projects should also be taken into consideration as well as local, regional and national regulations, laws and organizations, as they all impact each other. It must be understood that, at a local level there might be certain procedures and habits which impact environmental aspects of the EU Aid Programme, so the participation of local institutions and NGOs are essential in the success of any EU funded project in the TRNC.

Any environmental policy without appropriate legislation and support from the local institutions shall be fruitless, as they remain as legislations without enforcement. In 2012, the TRNC passed an Environmental Law as part of the harmonization process. It includes the protection of coastlines and coastal sea quality that incorporates sections on Environmental Protection, Waste Management, Water Resources Management, Urban Waste Water Management, Control of Marine Pollution, Air Quality Management, Industrial Pollution Control, Combating Climate Change and Conservation of Biodiversity, Environmental Assessment, Environmental Noise Management, Environmental Aesthetics, Environmental Information, Environmental Education, Inspection and Sanctions, and Crime and Punishments. In an interview, an EUCC official ${ }^{73}$ stressed that the 2012

${ }^{71}$ The EUCC was established in June 2003 under the Prime Minister's Office of the TRNC "to undertake the responsibility for coordinating, organizing and monitoring all the contacts and connections made or to be made under the European Commission Directorate General for Enlargement, and other EU Institutions and their collaborates such as United Nations Development Programme - Project for Future (UNDP- PFF)" with officials in north Cyprus. See "TRNC Prime Minister's Office of EU Coordination Centre". Accessed August 13, 2020. http://eu.kamunet.net/english/establishment_activities.html.

72 Anonymous [The EU Programme Support Office (EUPSO), Nicosia, TRNC], interview with the authors, Nicosia, 23 January 2020.

${ }^{73}$ Anonymous (TRNC Prime Minister's Office of EU Coordination Centre, Nicosia, TRNC), interview with the authors, Nicosia, 24 January 2020. 
Environmental Law might be seen as an outcome of the harmonization process, especially in the sense that, in the post-accession period, the EU framework has been generally seen as the best practice to be attained by local bureaucrats. In the same interview, the EUCC official pointed out the fact that the TRNC has delayed the harmonization process unlike their counterpart. While the northern part of the island has only taken "baby steps" towards the Europeanization process, the RoC embarked on Europeanisation in 1990 with their first application. Therefore, "the process of Europeanisation was not done under equal conditions". ${ }^{74}$

Although the TRNC has the internal sovereignty and full control to shape the social, monetary and political life in the north and has the legitimacy over its citizens, the problem of non-recognition, the uneasy relationship with the Greek Cypriot administration, and economic embargoes - have affected the citizens in time. Furthermore, incapacities in terms of internal sovereignty is also seen as one of the main problems hindering the harmonization process. ${ }^{75}$ Related to that, Lacher \& Kaymak $^{76}$ discuss that in time the legitimacy of the state has eroded and more Turkish Cypriots have begun to question whether this state truly mirrors their political will or not. There is wide scepticism in the ability of the TRNC's internal sovereignty especially in the post-2004 period. ${ }^{77}$ It may be for these reasons that the control of certain regulations is weak in the north of the island and even though the Environmental Laws are applied, it is easy to break as there are no effective control mechanisms. ${ }^{78}$ Protection of the environment therefore becomes more difficult to monitor by the governing bodies.

Non-recognition has been instrumental in promoting foreign investment and the northern part of the island is introduced as a booming, emerging market for property, banking and business investments. Such investment opportunities plan to attract entrepreneurs to invest in the TRNC. Also, the State Planning Organization of the TRNC issues incentives for all entrepreneurs. ${ }^{79}$ From an environmental perspective, this brings the dilemma

74 Anonymous, TRNC Prime Minister's Office of EU Coordination Centre.

75 Anonymous, TRNC Prime Minister's Office of EU Coordination Centre.

76 Lacher, Hannes, and Erol Kaymak, "Transforming Identities: Beyond the Politics of NonSettlement in North Cyprus." Mediterranean Politics, Vol. 10, No. 2 (2005), 147-166.

77 Lacher and Kaymak, Transforming Identities.

78 Anonymous, TRNC Prime Minister's Office of EU Coordination Centre.

79 At this point, while the state remains reluctant to impose any rules in order not to scare the investors with more bureaucratic procedures and costs, it becomes a big problem for the state, governments and the local authorities in charge such as the municipalities. Incentives for tourism entrepreneurs are based on the "Tourism and Industry Incentives Law". It can tax credits, reduced customs tax and exemption from taxes, duties, fees and all kinds of 
of promoting new investments in a place with weak control mechanisms and the problematic structural incapacities within the context of environmental governance are apparent in the north. In our interview with an EUCC official, the influence of investors regarding tourism has been also pointed out as critical. ${ }^{80}$ For instance, the historic harbour town of Kyrenia is faced with an extensive sewage problem. A local expert explained that in 1974, the coastal town had a population of 2,635 people (according to the 1973 census $)^{81}$. Over time, the town experienced a population boom resulting in what is thought to be a populace of around 100,000 today. Therefore, the town is unable to sustain this anymore. ${ }^{82}$ As previously mentioned, the local sewage treatment plant does not work efficiently meaning wastewater is directly pumped into the sea without proper treatment. The problem has been on the increase for a number of years and this is an unseen but terrible disaster. ${ }^{83}$ According to the Chamber of Environmental Engineers, the waste is much higher than the plant's capacity. "The capacity is 2,000 cubic meters per day, but there is more than 4,000 cubic meters of wastewater. And the sewage water is discharged directly into the sea". ${ }^{84}$ In the interviews conducted for this study, the EU officials acknowledged Kyrenia has a severe sewage problem, and they stated the willingness of the local authorities as well as the civil society and the EU Aid programme to collaborate to work for this cause. However, there is no enforcement of the EU law due to non-recognition as well as the limited public network capacity.

\section{Conclusion}

Preservation of the environment should be a common interest across the divide in Cyprus. The EU can see environmental issues as possible venues

contribution fees related to the construction permits including the stamp tax. (For more information, please see: https://www.kibrisgazetesi.com/amp/kibris/yatirimi-yap-tesvigikap-h67889.html.

80 Anonymous, TRNC Prime Minister's Office of EU Coordination Centre.

81 PRIO Cyprus has published the census figures of the town in their publications. For more information, please see PRIO report on displacement, (http://www.prio-cyprusdisplacement.net/default_print.asp?id=450).

82 Anonymous (A Local Expert, Nicosia, TRNC), interview with the authors, Nicosia, 23.01.2020.

83 Turker, Umut, Raed Bashitialshaaer and Hüseyin Gokcekus, "Wastewater management analysis for the main cities of Northern Cyprus." WATMED 2. (2005). Marrakech: Lund University.

84 Yenidüzen Gazetesi, 4 thousand cubic meters of wastewater is pumped into the sea per day. 
for promoting further dialogue, particularly by empowering and voicing the concerns of local players in cases where their presences and their voices are completely ignored due to political unrecognition. There is an urgent need for a more effective island-wide governance of environmental matters and the Union can provide the most instrumental framework on these grounds. It is seen that through Aid Regulation, the EU attempts to engage with the Turkish Cypriot community and by doing this, the EU aims to trigger a bottom-up demand of addressing such shared concerns but eventually faces limitations such as external sovereignty issues. The lack of external sovereignty and the erosion of the internal sovereignty of the TRNC restricts the implementation of the environmental laws. The treaties and the inefficiency of local structures make it even more difficult to cope with the ongoing environmental problems. The result of the process in terms of environmental protection as an element of environmental security is lack of bi-communal cooperation island wide due to the trap of non-recognition of the TRNC.

Based on these observations, this paper points out political and institutional limitations of European integration in the face of environmental change in north Cyprus and in the rest of the island. It can be concluded that due to ongoing political problems, the European integration and everyday policymaking in the field of environment has limited effects on domestic structures in Cyprus, which has also resulted in a number of interlocked environmental protection problems. Although the EU is designing various tools and instruments to address these threats in the northern part of the island, findings of this research indicate that an absence of local structures of environmental governance in the TRNC is as problematic as lack of international recognition and both make cooperation with the EU difficult for the EU officials in Cyprus.

This paper suggests that the EU can go beyond the trap of international recognition and local governance problems by emphasizing more the transboundary nature of environmental problems and bi-communal cooperation in Cyprus. Leveraging common environmental issues can be used as a ticket for cooperation between the two sides of the divide, and therefore it can further promote environmental cooperation. A sense of urgency of environmental change can help the EU to contextualize the matter within this framework to find sustainable linkages island wide that can assist in environmental protection and foster meaningful cooperation between the two communities. After all, cooperation is accepted as "a steppingstone towards 
rapprochement". 85 Therefore, environmental and natural resources can contribute to peace-building by supporting economic recovery; by facilitating the development of sustainable employment and by contributing to communication, cooperation and confidence-building measures. Finally, further studies can be done on more detailed analysis of the factors that influence effective coastal management in terms of environmental governance in the north.

\section{Bibliography}

Dresse, Anaïs, Fischhendler Itay, Jonas Ø. Nielsen and Zikos Dimitrios. "Environmental peacebuilding: Towards a theoretical framework." Cooperation and Conflict 54, no.1 (2019):99-119.

Aid Programme for The Turkish Cypriot Community. 2020. European Commission - European Commission. Accessed August 13. 2020. https://ec.europa.eu/info/funding-tenders/funding-opportunities/fundingprogrammes/overview-funding-programmes/aid-programme-turkish-cypriotcommunity_en.

Baldwin, David Allen. "The Concept of Security", Review of international studies 23, no. 1 (1997): 5-26.

Bilecenoğlu, Murat. "Controlling the Lionfish Invasion in the Eastern Mediterranean Sea", In Lionfish Invasion and Its Management in the Mediterranean Sea, ed. Fatih M. Hüseyinoglu and Bayram Ożturk. (Istanbul: Turkish Marine Research Foundation, TUDAV: 2018), 1-10.

Börzel, Tanja A., "Europeanization: How the European Union Interacts with its Member States", In The member states of the European Union. ed. Simon, Bulmer and Christian Lequesne, (USA: Oxford University Press: 2005), 45-69.

Börzel, Tanja, A. "Environmental Policy". In Europeanization: New Research Agendas. ed. Paolo \Graziano and Maarten Vink (Palgrave Macmillan: 2008), 226-238.

Börzel, Tanja and Thomas Risse, "Conceptualising the Domestic Impact of Europe", In The Politics of Europeanization. ed. Kevin Featherstone and Claudio M. Radaelli, (Oxford: Oxford University Press: 2003), 57-79.

Caporaso, James, "The Three Worlds of Regional Integration Theory". In Europeanization: New Research Agendas. ed. Paolo, Graziano and Maarten Vink, (Palgrave, Macmillan: 2008), 23-25.

\footnotetext{
${ }^{85}$ Hadjimichael and Papastylianou, Environmental protection and cooperation. pp. 17.
} 
“CELEX1, Council Regulation (EC) No 866/2004 Of 29 April 2004 On A Regime Under Article 2 Of Protocol 10 to the Act of Accession". Accessed August 13, 2020. https://op.europa.eu/en/publication-detail/-/publication/e68c4cc7-57834809-af6a-79d708db7a0c.

Constantinou, Costas M., and Yiannis Papadakis, "The Cypriot state (s) in situ: Cross-ethnic contact and the discourse of recognition". Global Society 15, no. 2 (2001): 125-148.

Coppieters, Bruno. “'Statehood', 'de facto Authorities' and 'Occupation': Contested Concepts and the EU's Engagement in its European Neighbourhood." Ethnopolitics 17, no. 4 (2018): 343-361.

Creswell, John W., and J. David Creswell. Research Design: Qualitative, quantitative, and mixed methods approaches. (Los Angeles, Sage: 2017).

CYPRUS: Sewage spills, sea pollution the norm for historic harbour town. (2019, September 22). Financial Mirror. Accessed March 09,2021. https://www.financialmirror.com/2019/09/22/cyprus-sewage-spills-seapollution-the-norm-for-historic-harbour-town/

Department of Environment. (2020). Retrieved from Ministry of Agriculture, Rural Development and Environment: http://www.moa.gov.cy/moa/environment/environmentnew.nsf/page03_en/pag e03_en?OpenDocument

De Waal, Thomas. Uncertain Ground: Engaging with Europe's de Facto States and Breakaway Territories. (Massachusetts: Carnegie Europe: 2018).

Bouris, Dimitris and George Kyris, "Europeanisation, Sovereignty and Contested States: The EU in Northern Cyprus And Palestine". The British Journal of Politics and International Relations, 19 (4): 755-771(2017). doi:10.1177/1369148117727534.

“EUR-Lex - 32006R0389 - EN - EUR-Lex". 2006. Accessed August 13, 2020. https://eur-lex.europa.eu/legalcontent/EN/TXT/?uri=CELEX\%3A32006R0389.

Global Environment Outlook 1: For Life On Earth". 1997. UNEP. Accessed August 13,2020. https://www.unenvironment.org/resources/report/global-environmentoutlook-1-life-earth

Gündem Kıbrıs Gazetesi. “Balıkçıların Sorunları Neler?” Gündem Kıbrıs Gazetesi, 11 Nov. 2020, Accessed March 12, 2021. www.gundemkibris.com/kibris/balikcilarin-sorunlari-neler-h302654.html.

Hadjimichael, Maria and Klitos Papastylianou, "Environmental protection and cooperation in an (ethnically) divided island: The case of Cyprus", Report 6/2019\Peace Research Institute Oslo (PRIO), Norway 
Havadis. "People are Hit by the Fear of Sewage," July 16, 2017, accessed August 13, 2020, https://www.havadiskibris.com/lagim-korkusu-plajlari-vurdu/.

"Integrated Coastal Management - Environment - European Commission". 2020. Accessed August 13, 2020. https://ec.europa.eu/environment/iczm/index_en.htm.

Ker-Lindsay, James. "Engagement without recognition: The limits of diplomatic interaction with contested states". International Affairs 91, no. 2 (2015): 267285.

Kerr, Pauline, "Human security and diplomacy." In Cavelty, Myriam Dunn, and Victor Mauer, eds. The Routledge Handbook of Security Studies. Routledge, 2010. pp. 115-127.

Kıbrıs Ada Haber. "KKTC Sahilleri İçin Tehlike," October 30, 2013, accessed August 13, 2020. https://www.kibrisadahaber.com/mobi/kktc-sahilleri-icintehlike.html.

Kıbrıs Gazetesi. "Arıtma yetersizliği felakete dönüşüyor," October 06, 2019, accessed August 13, 2020. https://www.kibrisgazetesi.com/kibris/aritmayetersizligi-felakete-donusuyor-

h75007.html?_cf_chl_jschl_tk_=5a8339ef0b91ce26f5b6a9c58a47361aaea18 83f-1580334695-0-

Ac_wJfbvhrav_pTBrxsaEG110kcR0oR1lRqX4K6ysfA87Hqp8iJ9x0kvuYb NdpDvEwZsqR $\overline{6 k} 7$ DFFd_cc4idSsqMPLl

Killaris, Kyriacos, "Global warming brings jellyfish invasion," August 10, 2020. Accessed August 14, 2020. https://www.financialmirror.com/2020/08/10/global-warming-brings-jellyfishinvasion/

Kyris, George. "The European Union and Cyprus: The Awkward Partnership." Euractiv. April 2, 2013, accessed August 13, 2020. https://www.euractiv.com/section/euro-finance/opinion/the-european-unionand-cyprus-the-awkward-partnership/.

Kyris, George. The Europeanisation of Contested Statehood: The EU in northern Cyprus. Routledge, 2016.

Kyris, George. "Sovereignty and engagement without recognition: Explaining the failure of conflict resolution in Cyprus." Ethnopolitics 17, no. 4 (2018): 426442.

Lacher, Hannes, and Erol Kaymak, "Transforming Identities: Beyond the Politics of Non-Settlement in North Cyprus." Mediterranean Politics, Vol. 10, No. 2 (2005), 147-166. 
"Marine Environment". European Environment Agency. February 18, 2015. Accessed August 13, 2020. https://www.eea.europa.eu/soer2015/europe/marine-and-coastal\#tab-based-on-indicators.

McDonald, B. L., Matthew, R., Barnett, J., \& O'Brien, K. (2009). Global Environmental Change and Human Security. The MIT Press.

Gündüz, Şerife (The President of "The Bi-communal Technical Committee on Environment" in Cyprus), interview with the authors, February 15, 2020, Nicosia.

Ward, Nora, "Microplastic Pollution is at An All-Time High in Cyprus," Pacific Standard, November 26, 2018, accessed August 13, 2020, https://psmag.com/environment/microplastic-pollution-is-at-an-all-time-highin-cyprus.

Nowell, Lorelli S., Jill M. Norris, Deborah E. White, and Nancy J. Moules. "Thematic analysis: Striving to meet the trustworthiness criteria." International journal of qualitative methods 16, no. 1 (2017): 1609406917733847.

Özden, Özge Fuller (Academic, Near East University, Cyprus), interview with the authors, February 21, 2020, Nicosia.

Özden, Özge Fuller, Sinem Yıldırım, Wayne J. Fuller, and Brendan J. Godley. "Anthropogenic marine litter on the north coast of Cyprus: Insights into marine pollution in the eastern Mediterranean.” Marine Pollution Bulletin 165 (2021): 112167.

Radaelli, Claudio. M. and Romain Pasquier. Conceptual Issues. In Europeanization New Research Agendas, ed. Graziano, P. and Vink, M. (Bas'ngstone: Palgrave/ Macmillan: 2008), 35-46.

Scientific American, "COVID-19 Has Worsened the Ocean Plastic Pollution Problem", August 17, 2020. Accessed August 17, 2020, https://www.scientificamerican.com/article/covid-19-has-worsened-the-oceanplastic-pollution-problem/.

“Security Council Resolution 541 - UNSCR". 1983. UNSCR. Accessed August 13, 2020. http://unscr.com/en/resolutions/541.

“Security Council Resolution 550 - UNSCR". 1984. UNSCR. Accessed August 13, 2020. http://unscr.com/en/resolutions/550.

Jarraud, Nicolas Stephane and Alexandros Lordos, "Participatory approaches to environmental conflict resolution in Cyprus". Conflict Resolution Quarterly, 29, no. 3 (2012): 261-281.

"The Causes of Climate Change." NASA. February 8, 2021. https://climate.nasa.gov/causes/. 
“The Global Risks Report 2020”. 2020. World Economic Forum. Accessed August 13, 2020. https://www.weforum.org/reports/the-global-risks-report-2020.

“TRNC Prime Minister's Office of EU Coordination Centre”. Accessed August 13, 2020. http://eu.kamunet.net/english/establishment_activities.html.

Turker, Umut, Raed Bashitialshaaer and Hüseyin Gokcekus, "Wastewater management analysis for the main cities of Northern Cyprus." WATMED 2. (2005). Marrakech: Lund University.

UNDP. 1994. Human Development Report 1994: New Dimensions of Human Security. Accessed August 13,2020. http://www.hdr.undp.org/en/content/human-development-report-1994.

“6: World Oceans and Coastal Zones.” IPCC. Accessed March 14, 2021. https://www.ipcc.ch/report/ar1/wg2/world-oceans-and-coastal-zones/.

Yenidüzen Gazetesi, “Outdated Sewage Plant Damaging Environment," June 06, 2018. Accessed August 13, 2020. https://www.lgcnews.com/outdated-sewageplant-damaging-environment/.

Yenidüzen Gazetesi, "4 thousand cubic meters of wastewater is pumped into the sea per day," June 06, 2018. Accessed August 13, 2020. http://www.yeniduzen.com/gunde-4-bin-metrekup-atik-su-denizepompalaniyor-103212h.htm.

Yenidüzen Gazetesi, "Waste is Swimming Not People," September 5, 2017. Accessed August 13, 2020. http://www.yeniduzen.com/insanlar-degil-atiklaryuzdu-93587h.htm. 
